\author{
Yu. Kim ${ }^{1, *}$, A. Omarova ${ }^{2}$ \\ ${ }^{1,2}$ Karaganda University of Kazpotrebsoyuz, Karaganda, Kazakhstan \\ Iego-uk@mail.ru,2ainuraphd@mail.ru \\ ORCID ID ${ }^{1}$ https://orcid.org/0000-0001-8990-1400, \\ ${ }^{2}$ https://orcid.org/0000-0001-9808-4908
}

\title{
Features of personnel management in the public service system of the republic of Kazakhstan
}

\begin{abstract}
Object: It is a social relations, developing in the sphere of formation of the civil service in the Republic of Kazakhstan. National and other countries experience indicate that it is impossible to create an effective public service system without developing scientifically based and verified concepts and features of personnel management in the public service system, which would eliminate systemic contradictions in the legal regulation. The growth of scientific interest in the problems of theory and practice of public service has objective grounds of the study.

Methods: Methods of grouping and classification, as well as methods of mathematical modeling, were used in the processing and systematization of data. An econometric model was constructed.

Findings: While investigating the features of personnel management in the system of civil service of Kazakhstan, it was revealed that the civil service is based on certain principles, on the basis of which it is possible to carry out personnel planning to respond to changes in the needs of the public service. The authors hypothesized, there is a relationship between the indicator "Services in the field of public administration; services in the field of mandatory social security" and the factor "The list number of employees in the field, mandatory social security" and "The average monthly salary of civil servants". A regression analysis was performed to prove or disprove this hypothesis.

Conclusions: Based on the analysis we can say with confidence, the hypothesis put forward about the relationship between the indicators in previous stage are confirmed.

The authors comes to the conclusion that the staffing of civil servants is a necessary management process, since the effectiveness of the activities of public authorities is largely determined by the quantity and quality of resources for effective public administration.
\end{abstract}

Keywords: public service, civil service, governance, development strategy, staffing, communication, innovation, management.

\section{Introduction}

The public service is one of the most important mechanisms for shaping public policy, since it is within the framework of this institution that processes are generated that directly affect the direction and content of the political course, the choice of social priorities and the definition of political and economic strategies.

Today, almost all countries of the world take an active position in the framework of legal support for the institution of public service. In each country, the organizational issues of the state apparatus are among the key ones. The Institute of public administration in modern countries thanks to the legislative design has gained quite clear contours that distinguish politicians in the public administration, where one of the most important problems of public personnel management services is the formation and development of personnel potential as a multidimensional and complex process, which shows the relationship of legal, regulatory and procedural aspects and the expected enrichment of many social and managerial settings, first of all, such as the professional growth of employees, changes in their social values, moral attitudes, changes in the age, professional qualification, tender structure of personnel, and other quantitative and qualitative characteristics.

Today, as a result of consistent reforms in Kazakhstan, a unique model has been created based on the principles of meritocracy, efficiency and accountability to society. In the framework of realization of the Plan "100 steps" improved systems of recruitment, training and promotion of personnel, introduce modern human resource management tools to improve the quality of civil servants.

\footnotetext{
${ }^{*}$ Corresponding author.

E-mail address: ego-uk@mail.ru
} 
International experts say that the main condition for success in modernizing the civil service is the political will of the President of the country to develop and strengthen statehood.

\section{Literature Review}

Administrative reforms and, in particular, civil service reform in post-Soviet countries in the last 25 years was due not just to the need to implement state-building in the former Soviet republics, but also the influence of global trends associated with the crisis of the welfare state, social tectonic shifts in the modern world, where the emergence of supranational institutions and the development of civil society necessitated a serious transformation of the traditional ("Weberian") model of public administration (Bespalov, 2015).

In their research Dosymbekova R.Sh. focuses on the personnel component in the process of implementing administrative reform, transformation and optimization of state bodies. The issues of organizational efficiency, new technological processes in the activities of civil servants are considered. The formation of Kazakhstan's statehood is closely interrelated with a wide range of issues of theoretical and practical understanding of personnel management in the public service system (Dosymbekova, 2015).

According to Sheluntsov A.M., the improvement of the personnel management system is currently a priority of the strategic goals for the development of the personnel policy of any organization (Sheluntsova, 2018). This issue is particularly acute for state institutions, since at the moment there is an increase in the complexity of all aspects of the functioning of the state body (Suleimenova, 2016).

Constitutional changes in the field of public administration reform in Kazakhstan are links in one logical chain of strategic changes in the policy of forming a strong state (Zhumagulov, 2019).

High-quality public administration should become one of the factors that ensure sustainable economic development, improve the quality of life of the population and increase the overall competitiveness of the state. For Kazakhstan, the significance of the concept of state management is determined primarily by the search for approaches that are adequate to the new realities, aimed at improving the management system, introducing market mechanisms into state and local management structures, as well as developing the economy of Kazakhstan (Kadyrov et al., 2016).

In her research, E. A. Bakhtairova conducts a comparative analysis of the civil service organization systems of Russia's partner countries in the Eurasian economic Union (Belarus, Armenia, Kazakhstan, and Kyrgyzstan). The modern civil service is an institution designed to ensure the fulfillment of state powers, the implementation of laws and functions of the state. After its transformation, which took place in all countries in the post-Soviet space in the 1990s and 2000s, it acquired some common features, which were determined by the ideology of reforming States and their institutions based on the experience of foreign countries, mainly models of the continental and Anglo-Saxon type, while maintaining some differences. Further development of States in the context of modern world trends, the emergence of new challenges in the early XXI century led to changes in the systems of legislation on public service (Bakhtairova, 2019).

Today, the issue of finding ways to ensure the global competitiveness of this integration Association is relevant, where one of the basic factors for ensuring global competitiveness is the effectiveness of state institutions, one of which is the Institute of public service (Meteleva E.R., Anufrieva A.A., Devyatova N.S, 2019).

In accordance with the statement of Baranova S. A., the state service is interpreted as an institution for conducting public Affairs, implementing laws and functions of the state (Baranova, 2018).

The Law of the Republic of Kazakhstan "on public service" does not directly distinguish the types of public service, but it is noted that the law applies to: all civil servants; administrative civil servants appointed by local representative bodies; civil servants undergoing law enforcement service, with the features provided for by legislative acts of the Republic of Kazakhstan on law enforcement service (State Law, 2020).

Conducting research on the main reference models of the Institute of public service, Mamitova N.V. noted that in all States, without exception, the historical experience of the formation and development of the Institute of public service is used. The main attention in the process of state-legal transformations is focused on effective technologies and principles of organization and activity of officials (Mamitova, 2017).

Stelina J. on the basis of system-structural analysis, as well as comparative legal comparison, examines the conceptual foundations of the legal status of civil servants in the legal systems of States, where he con- 
siders theoretical models of the legal institution of public service, determining the place of this institution in the legal system (Stelina, 2019).

In his research, Borshchevsky G. A. States that the civil service is a political and administrative institution created to meet the needs for professional execution of political decisions and ensuring daily contact between society and the institutions of political power (Borschevskiy, 2018).

\section{Methods}

Public service as a specific, professional activity of a special layer of people associated with the performance of managerial functions in society is based on certain principles, which are expressed in the form of requirements that ensure the functionality of the institution of public service as a whole.

Investigating the features of personnel management in the public service system of the Republic of Kazakhstan, we note that in total, the public service in Kazakhstan consists of almost 100,000 people, the vast majority of whom (almost 98,000) belong to the "B"corps. For a clearer understanding of the division of civil servants into categories, we define their meaning (Figure 1).

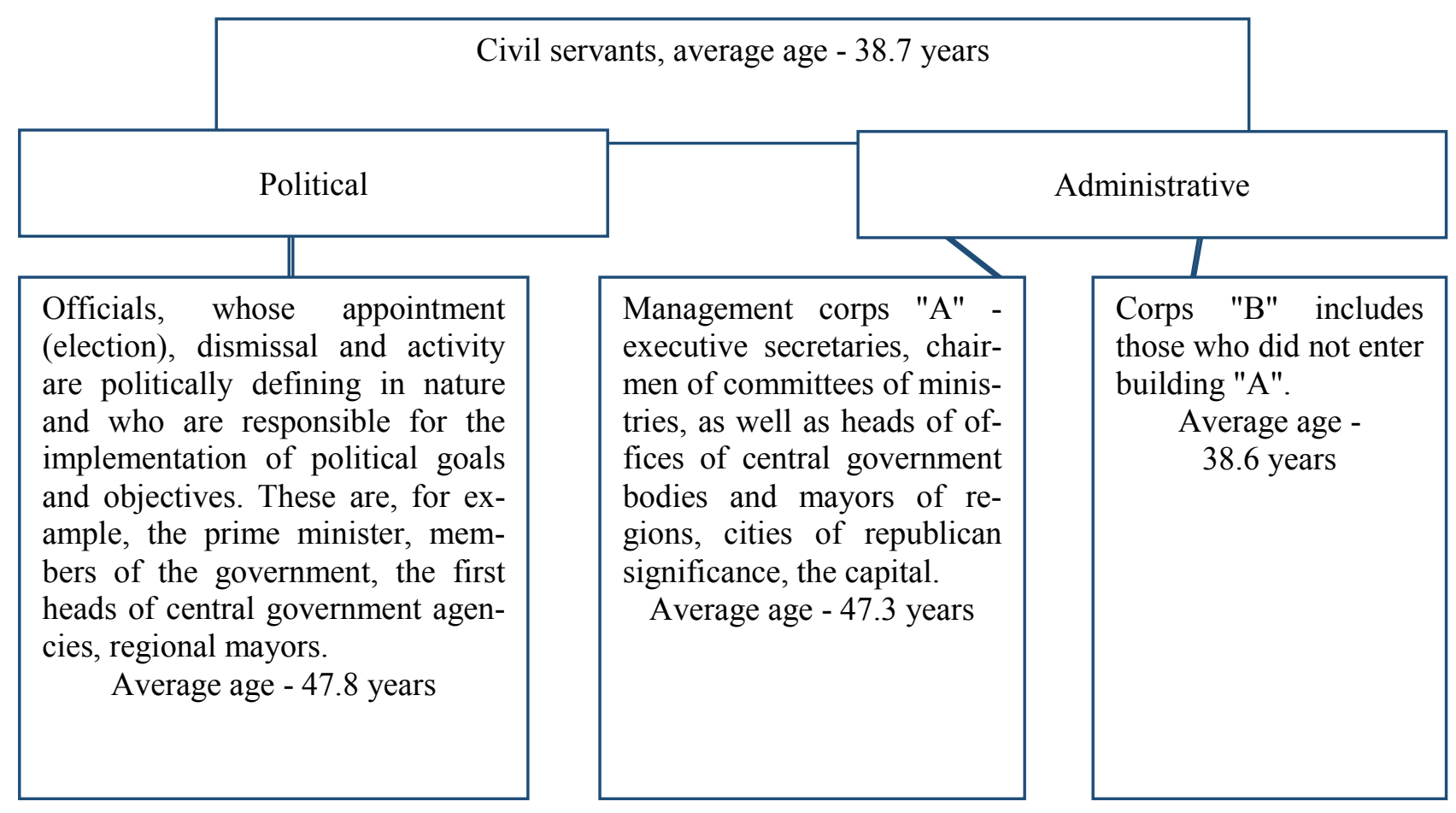

Note-Compiled by the authors

Figure 1. Classification features of civil servants

Exploring the features of personnel management in the civil service system of the Republic of Kazakhstan, we note that in total, almost 100,000 people are employed in the civil service in Kazakhstan, the vast majority of whom (almost 98,000 ) belong to the "B" corps.

Compared to 2017, the number of employees of the "A" corps has decreased by more than a third: from 519 to 279 people; however, the number of employees of the "B" corps has not changed much. This reduction is more noticeable in Central state bodies (from 207 to 63 people) than in local ones (from 296 to 216 people) (Data of The Agency for Public Service and Anti-Corruption, 2018).

The report "Monitoring the state of civil service personnel" does not contain information on the degree of quantitative and qualitative compliance of personnel in various categories with the tasks set, as well as on the reasons for increasing or reducing the number of certain groups of civil servants (National report, 2020). However, it is noted that the number of civil servants in senior management positions has decreased in Kazakhstan (Table 1) (Data of The Agency for Public Service and Anti-Corruption, 2018). 
Table 1. Number of civil servants in senior management positions.

\begin{tabular}{|l|l|l|}
\hline Indicators & 2017 & 2018 \\
\hline Full-time number of civil servants & 98272 & 98499 \\
\hline Politicalcivilservants & 433 & 436 \\
\hline - Corps "A" & 519 & 279 \\
\hline - Corps"B" & 97753 & 97784 \\
\hline Civil servants in central government structures & 52616 & 52409 \\
\hline Civil servants in central offices & 10059 & 10233 \\
\hline -Politicalcivilservants & 326 & 326 \\
\hline - Corps "A" & 207 & 63 \\
\hline - Corps"B" & 9526 & 9844 \\
\hline - Corps “A" (in territorial divisions) & 16 & $*$ \\
\hline - Corps "B" (in territorial divisions) & 42541 & 42176 \\
\hline Localgovernmentstructures & 46089 & 46090 \\
\hline - Politicalcivilservants & 107 & 110 \\
\hline - Corps "A" & 296 & 216 \\
\hline - Corps"B" & 45 686 & 45764 \\
\hline $\begin{array}{l}\text { Note - Compiled on the basis of the source: Agency for Public Service and Anti-Corruption (2018), Monitoring the state of civil } \\
\text { service personnel as of 2017-2018, http://kyzmet.gov.kz/ru/pages/monitoring-sostoyaniya-kadrov- gosudarstvennoy-sluzhby-po- } \\
\text { sostoyaniyu-na-1-yanvarya-2018-goda }\end{array}$ & \multicolumn{2}{|l}{} \\
\hline
\end{tabular}

According to the statistics Committee, in the first quarter of 2020, the list number of employees engaged in General public administration, as well as socio-economic management, amounted to 207.6 thousand people. A little less - 203.7 thousand people-are engaged in "providing public services to society as a whole." About a thousand more people are employed in the field of compulsory social insurance (Figure 2) (Data of Information and Analytical Center, 2019).

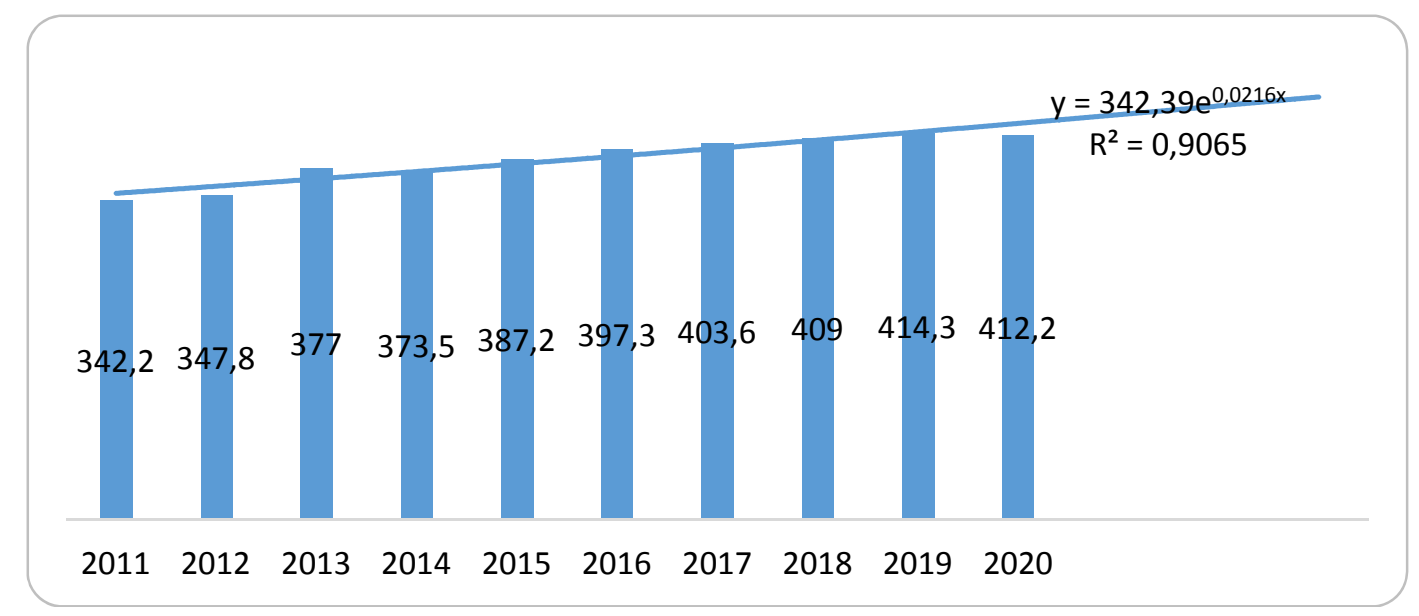

Figure 2. List number of employees in the sphere of "Public administration and defense; mandatory social security" at the end of the 1 st quarter of 2020, thousands of people

Note-Compiled on the basis of the source: Electronic resource: Data Of the Committee on statistics of the Republic of Kazakhstan for 2011-2019. //www.stat.gov.kz

Thus, the total number of employees in the sphere of "Public administration and defense; mandatory social security" is 412.2 thousand people. And this does not include teachers, doctors, or employees of cultural objects.

For example, the population of the Republic as of April 1, 2019 was 18 million 690 thousand people. Therefore, on average, there is one civil servant for every 44 people in the Republic (including infants and the elderly). In addition, in comparison with October-December 2019, the list number increased by $0.3 \%$ - 
this is approximately 1.2 thousand people. But over the year, the number decreased by $0.5 \%$. Civil servants make up $10.8 \%$ of all employees in the Republic.

\section{Results}

The author hypothesized that there is a relationship between the indicator "Services in the field of public administration and defense; services in the field of mandatory social security" and such factors as "The list number of employees in the field of "Public administration and defense; mandatory social security" and "The average monthly salary of civil servants". To prove or refute this hypothesis, a regression analysis of statistical data was performed (Table 2) (Data of the Committee on Statistics, 2019).

Table 2.Indicators characterizing public administration in the Republic of Kazakhstan for the period from 2011-2019

\begin{tabular}{|c|c|c|c|}
\hline Year & $\begin{array}{c}\text { Services in the field of public } \\
\text { administration and defense; services } \\
\text { for compulsory social security, } \\
\text { milliontenge }\end{array}$ & $\begin{array}{c}\text { The list number of employees in the } \\
\text { sphere of "Public administration and } \\
\text { defense; mandatory social security", } \\
\text { thousandpeople }\end{array}$ & $\begin{array}{c}\text { Average monthly } \\
\text { salary of civil } \\
\text { servants, } \\
\text { thousandtenge }\end{array}$ \\
\hline 2011 & 1009479,90 & 342,2 & 90 \\
\hline 2012 & 1225449,90 & 347,8 & 95,6 \\
\hline 2013 & 1386994,20 & 377 & 96,4 \\
\hline 2014 & 1516375,20 & 373,5 & 98,6 \\
\hline 2015 & 1708422,40 & 387,2 & 100,4 \\
\hline 2016 & 1645153,20 & 397,3 & 109,9 \\
\hline 2017 & 1814341,00 & 403,6 & 12,6 \\
\hline 2018 & 1948244,80 & 409 & 134,1 \\
\hline 2019 & 2316089,20 & 414,3 & \\
\hline $\begin{array}{l}\text { Note-Compiled by the author on the basis of the source: Electronic resource: Data of the Committee on Statistics of the Republic } \\
\text { of Kazakhstan for 2011-2019. //www.stat.gov. } k z\end{array}$ \\
\hline
\end{tabular}

The results of the regression analysis performed using the least squares method are shown in (Table 3).

Table 3. Results of the assessment of the equation of the volume of services in the field of public administration and defense; services for compulsory social security

\begin{tabular}{|l|l|}
\hline$R$ & 0,972 \\
\hline$R^{2}$ & 0,944 \\
\hline Adjusted R2 & 0,926 \\
\hline Fischer Test & $50,724 * * *$ \\
\hline Variables \\
\hline $\begin{array}{l}\text { Services in the field of public administration and defence services; compulsory social security (million KZT) is } \\
\text { the dependent variable }\end{array}$ \\
\hline Constant & $-2711701,716^{* * *}$ \\
\hline \multicolumn{2}{|l|}{ Regression coefficients } \\
\hline $\begin{array}{l}\text { List number of employees in the field of } \\
\text { "Public administration and defense; } \\
\text { mandatory social security" (thousand } \\
\text { people) }\end{array}$ & $7433,355^{*}$ \\
\hline $\begin{array}{l}\text { Average monthly salary of civil servants } \\
\text { thousand tenge) }\end{array}$ & $13857,095 * *$ \\
\hline * p $<0,1 ; * * \mathrm{p}<0,05 ; * * * \mathrm{p}<0,01$ \\
\hline Note - Compiled by the author \\
\hline
\end{tabular}

The calculations showed that the value of the multiple correlation coefficient for the model $\mathrm{R}=0.972$ is close to 1 , so we can talk about a strong correlation between the resulting variable and the factors under consideration. The regression equation as a whole, as well as its individual parameters, are statistically significant and reliable, at appropriate levels of significance. 
Therefore, having obtained a positive value in the regression equation of the effective indicator, we can say with confidence that our hypothesis about the relationship between the indicator "Public administration and defense services; mandatory social security services" and the factors "List number of employees in the field of Public administration and Defense; mandatory social security "and" Average monthly salary of civil servants "is confirmed.

We estimate the degree of influence of each factor on the resulting variable, for which we calculate the average elasticity coefficients for the aggregate:

$$
E_{1}=1.761 \%, E_{2}=0.914 \%
$$

The results obtained indicate that the factor "List number of employees in the field of Public administration and defense; mandatory social security" has a greater impact on the volume of services in the field of public administration and defense; services for mandatory social security than the factor "Average monthly salary of civil servants".

Most OECD countries have a human resources planning system that ensures that there is sufficient human resources to provide the necessary public services. Kazakhstan is one of the countries where there are no orderly HR planning processes. HR planning helps you anticipate the future and respond to changing public service needs in cost-effective ways. If we consider by type of economic activity, the situation is as follows (Figure 3) (Data of Information and Analytical Center, 2019).

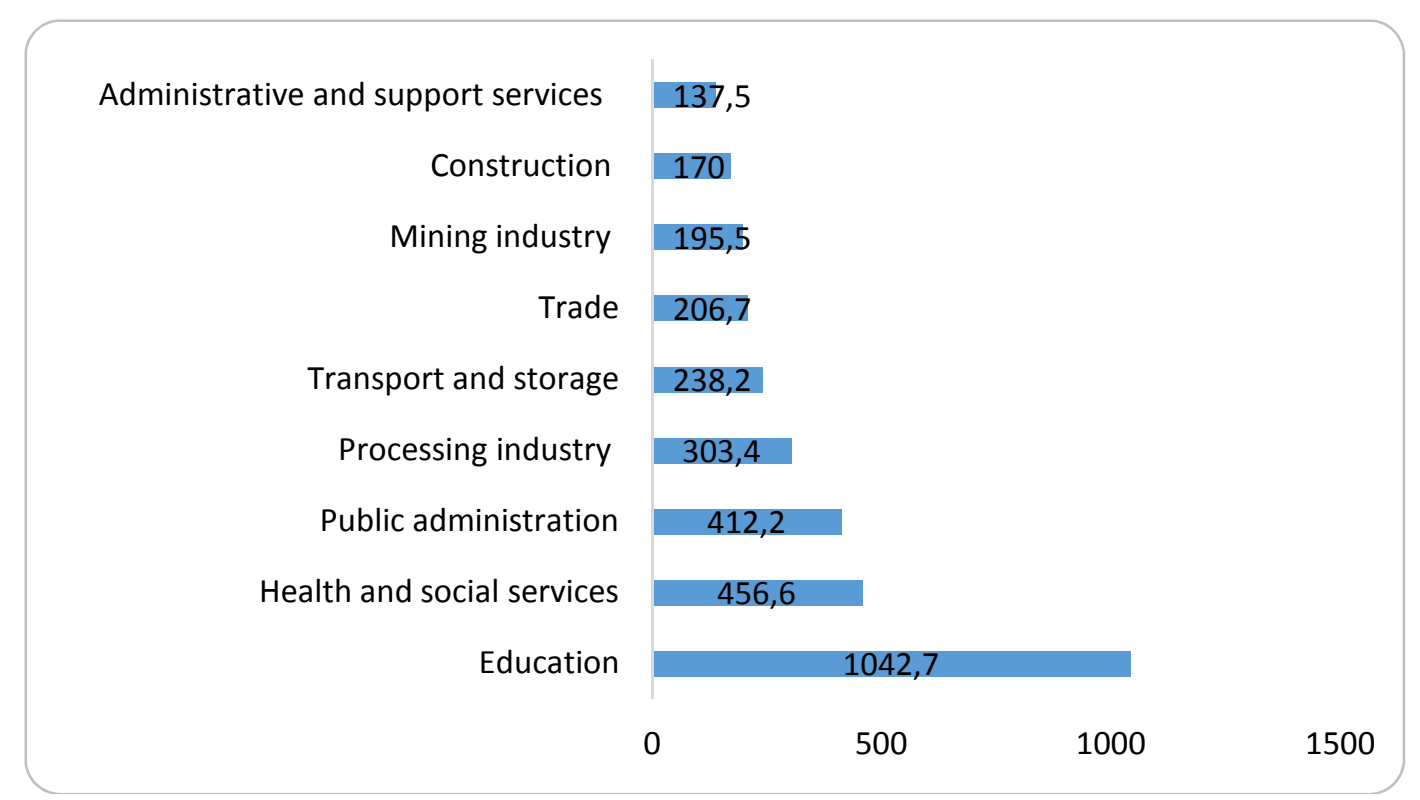

Figure 3. Types of economic activities with the largest number of workers (thousand people per 1sq. 2020)

Note-Compiled on the basis of source: Electronic resource: the Data of the statistics Committee of the Republic of Kazakhstan for 2011-2019. //www.stat.gov.kz

In the public administration and defense a third more workers than in the whole manufacturing industry, twice that in trade and 6 times more than in agriculture.

The results of the evaluation of the effectiveness of human resources management in public bodies of Kazakhstan, conducted by the Astana hub in the field of civil service and the United Nations development Program (UNDP), allow us to conclude that in terms of the number of civil servants, human resources potential is a problem for the country's public administration.

The nature of education of civil servants in Kazakhstan is quite diverse, which can be considered an advantage, since public procurement requires versatile skills. The majority of civil servants with higher education studied Economics or business $(37.5 \%)$ or law $(25.3 \%)$. Other popular areas of education include technical Sciences and technology $(9.3 \%)$ or education $(7.5 \%)$.

If we consider the regional aspect, the list number of employees employed in public administration is as follows (Figure 4) (Data of Information and Analytical Center, 2019). 


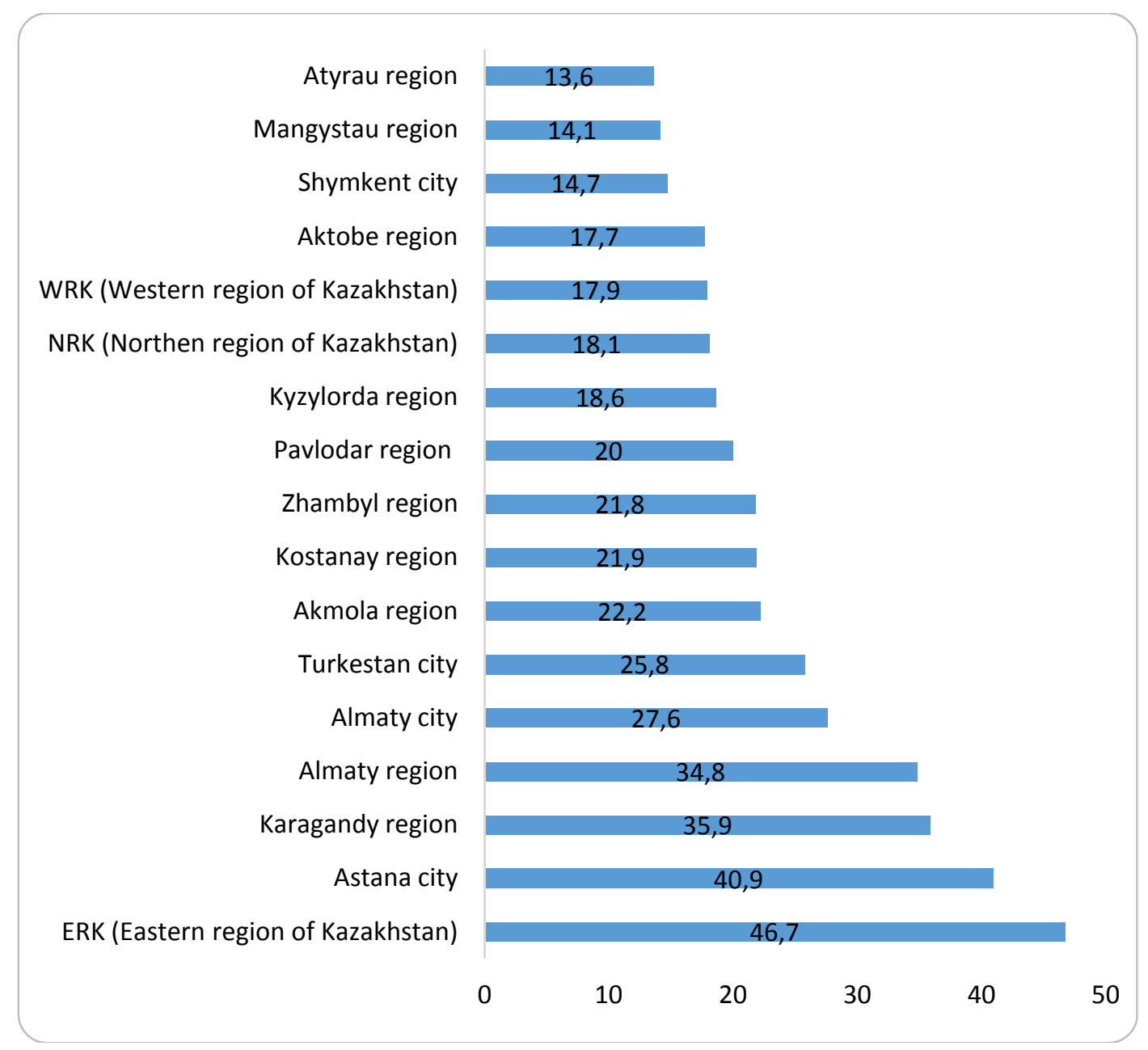

Figure 4.Payroll number of workers employed in government administration in the regions of Kazakhstan (thousand people per 1sq. 2020.)

Note - Compiled on the basis of source: Electronic resource: the Data of the statistics Committee of the Republic of Kazakhstan for 2011-2019. //www.stat.gov.kz

Nur-Sultan located both for the city and Republican authorities. Therefore, the number of civil servants in the capital is large -40.9 thousand people. But this region is not a leader - there are almost $15 \%$ more of them in the East Kazakhstan region.

In the North Kazakhstan region, the region with the smallest population, there are a quarter more civil servants than in Shymkent - a city of national significance, which has twice as many people as in the entire North Kazakhstan region.

In the two-million-strong Almaty region, there are 35\% more officials than in the Turkestan region, where only 38 thousand fewer people live

In the Turkestan region, there are 12.8 civil servants per 1000 inhabitants, and in Almaty and Shymkent - just over 14. In Nur-Sultan - more than 35, East Kazakhstan and North Kazakhstan regionsmore than 33.

If we consider the situation in the size of the gender, men significantly predominate. Their list number at the end of the first quarter was 262 thousand people against 150.3 thousand women. Moreover, there is no area where the situation was the opposite.

The most "male" regions are located in the South: the share of women in the civil service in Shymkent is 23.8\%, in the Turkestan region-26.7\%, in Almaty - 31.5\%. The highest percentage equality is in the Pavlodar region, where the share of women is $46.5 \%$ (Figure 5) (Data of Information and Analytical Center, 2019). 


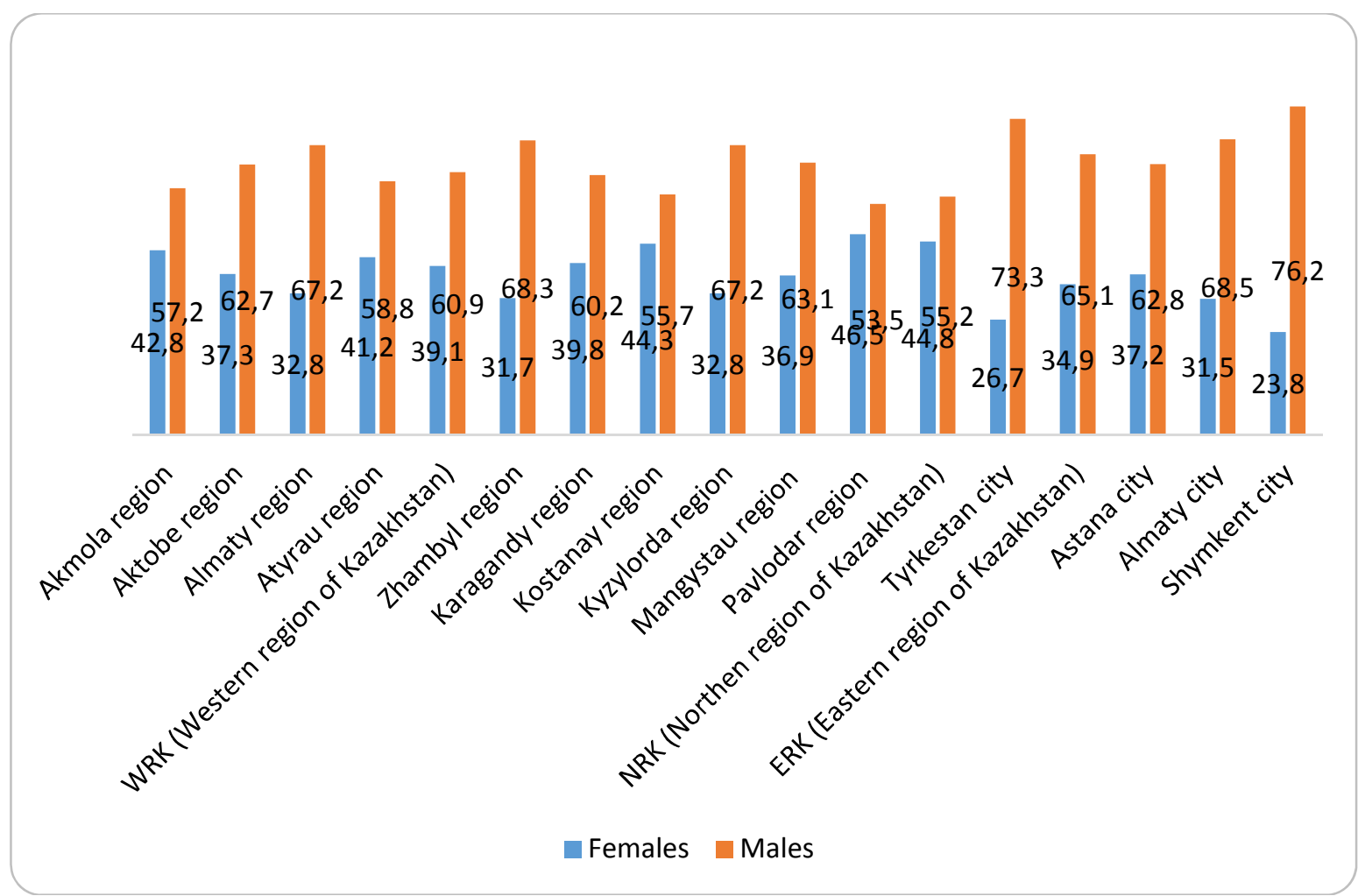

Figure 5.Share of employees employed in public administration by regions of Kazakhstan by gender (in 1q20)

Note-Based on the source: Electronic resource: Data Of the Committee on statistics of the Republic of Kazakhstan for $2011-2019$. //www.stat.gov.kz

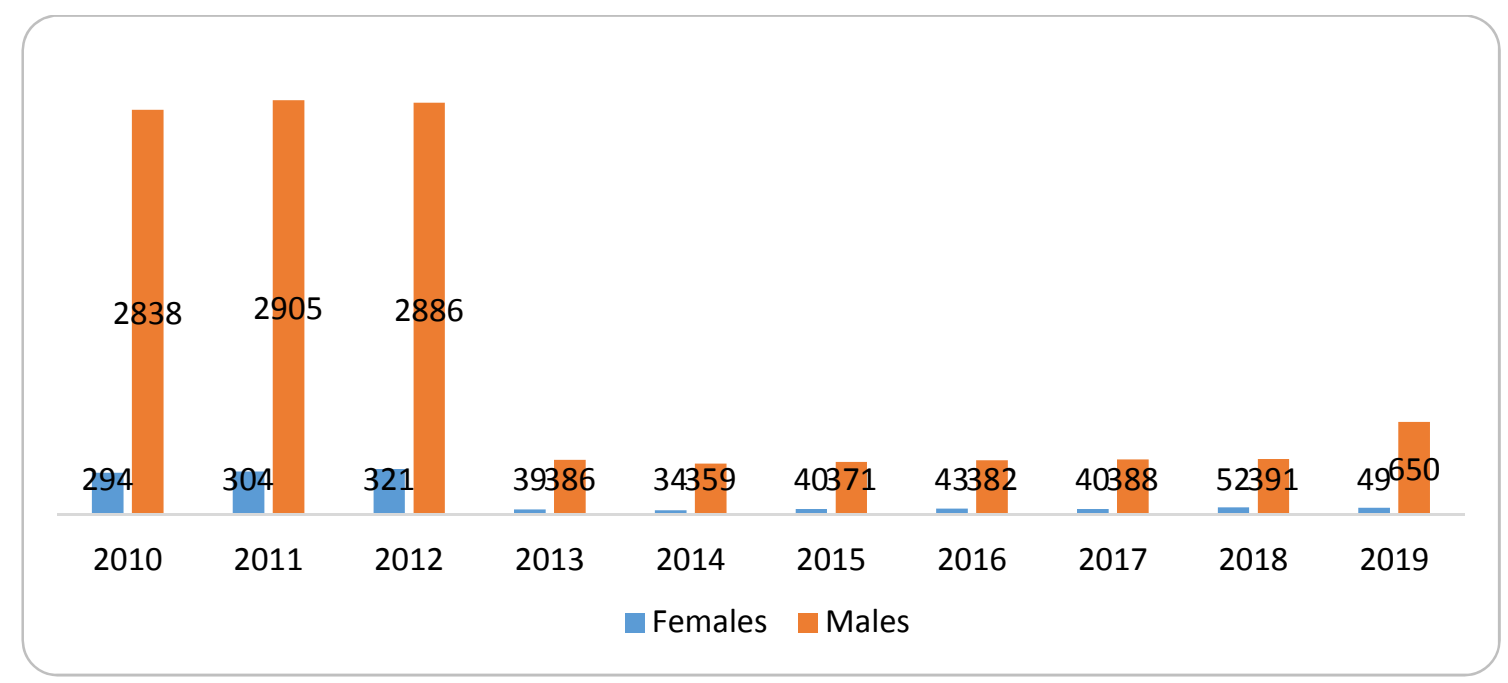

Figure 6. Total civil servants by gender for the period from 2010-2019, people

Note-Compiled on the basis of the source: Electronic resource: Data Of the Committee on statistics of the Republic of Kazakhstan for 2011-2019. //www.stat.gov.kz

More than $50 \%$ of all employees are under the age of 34 . The share of young people only in financial and insurance activities is higher (54.2\%). At the same time:

- there are more civil servants under the age of 24 than employees of information and communications, financial and insurance activities, and real estate operations combined; ities;

- at the age of 24-28 years-more than in health care, mining, professional, scientific and technical activ-

- at the age of 29-34 years-more than in the manufacturing industry. 
The share of employees aged $45-54$ years is only $15 \%$ - there is no less in any other type of economic activity. There are only $6 \%$ of pre-retirement employees in the state administration. This is almost half as much as in healthcare and industry.

At the same time:

- more men work in the public service than in the mining sector, education, water and electricity supply;

- there are more women in the civil service than in the catering, hotel sector, transport companies, administrative and auxiliary services, as well as in the field of entertainment and recreation.

According to experts, today the Kazakh public service meets international standards in many respects, and is ahead of them in some respects. Thus, Kazakhstan, unlike a number of developed countries, has avoided the problem of aging of the state apparatus and gender imbalance. Today, the average age of a civil servant is 39, compared to 44 in 1991. 55\% of women work in the civil service in Kazakhstan, while in Italy, Belgium, and Spain this figure is 50\% (Data for Benchmarking Civil Service Reform, 2018).

"OECD experts assess Kazakhstan's public service as professional, with strategic elements. In practice, this means that-due to the fact that the principle of meritocracy has been introduced for civil servants. Personnel selection is based on competencies, and ethical requirements are standardized. As for the strategic elements, our system is characterized by attractiveness, as well as the ability to quickly respond to changes (Data of Information and Analytical Center, 2019).

In the current year 2020, in order to further improve the selection tools for the administrative public service, taking into account the recommendations of the OECD, the following tasks are proposed::

- introduction of direct competitive selection for corps a positions, which minimizes the possibility of politicization of such appointments and will help attract professionals from the private sector;

- working out a step-by-step transition from checking the candidates of the corps "B" for knowledge of the law in favor of determining their level of competence, while expanding the Agency's role in the selection for public service.

As measures aimed at further improving the public service system and ensuring the transition to the next stage of development of the state apparatus-the strategic innovation model, the following should be attributed:

1) study the possibility of introducing strategic personnel planning, as well as institutional improvement of the civil service;

2) working out the issue of introducing the practice of moving on the "center-region" principle for employees of the highest Central state bodies with the possibility of returning to the sending body;

3) modernizing the selection system for posts of corps "A" with the introduction of direct competition, and the transition from the verification of candidates for corps "B" on the knowledge of the law in favor of determining their level of competence by expanding the Agency's role;

4) continue work on optimizing the expenses of state bodies and subordinate organizations for the transition to a new system of remuneration;

5) elaboration of the issue of conceptual revision of the Law "on public services", including the introduction of the concept of " socially significant service»;

6) study of the optimal ratio of industry and support personnel, the feasibility of introducing the Institute of contract civil servants;

7) working out the issue of building an optimal management structure for the state apparatus, retaining strategic and regulatory functions for state bodies, and transferring implementation functions to subordinate organizations.

\section{Conclusions}

The current stage in the country's development, the high turbulence of the global situation, the steadily increasing gap between developed and developing countries, and, as a result, the complexity and versatility of the tasks facing Kazakhstan, require qualitatively new approaches to public administration, where an effective state personnel policy should become a powerful tool for transforming the state's activities in all areas.

The results obtained indicate that the factor "List number of employees in the field of Public administration and defense; mandatory social security" has a greater impact on the volume of services in the field of public administration and defense; services for mandatory social security than the factor "Average monthly salary of civil servants". 
The formation of a modern, professional and Autonomous state apparatus and its continuous improvement is one of the decisive factors for the further stable and progressive development of Kazakhstan, as well as its response to global challenges.

Thus, based on the analysis of the state of public service personnel, several goals can be identified, the implementation of which will significantly increase the efficiency of personnel work in state bodies and increase the level of professionalism of employees:

- first, a competitive environment should be created in the system of the state apparatus with the involvement of modern technologies and high innovation management;

- secondly, it is necessary to ensure a close two-way relationship with civil society, which implies a deep involvement of state authorities and the General public in the formation of regulations governing the activities of the civil service.

\section{References}

Anufrieva, A.A., Devyatova, N.S., \& Meteleva, E.R. (2019). Global Competitiveness Ensuring as a Main Priority of Cooperation in the Eurasian Economic Union area. Sbornik izbrannykh statei po materialam nauchnyk konferentsii GNII «Natsrazvitie» - Selection of Scientific Conferences Papers of Public Research Institute «Natsrazvitie». Saint Petersburg: Economic Sciences [in Russian].

Bakhtairova E.A. (2019). Formation of a New Paradigm of Public Service in the Post-Soviet Eurasian Economic Union Countries (Belarus, Armenia, Kazakhstan and Kyrgyzstan). Izvestiya Baikal'skogo gosudarstvennogo universiteta Bulletin of Baikal State University, 29(2), 273-279. DOI: 10.17150/2500-2759.2019.29(2).273-279

Baranova, S.A. (2018). Service Law as a New Branch of Russian Law: Problems of Formation and Development. Voprosy rossiiskogo i mezhdunarodnogo prava - Matters of Russian and International 8, 3A, 64-70 [in Russian].

Bespalov, S.V. (2015). Reforming Civil Service in Kazakhstan. Modern Research of Social Problems, 11(55), 132-148. DOI: $10.12731 / 2218-7405-2015-11-12$

Borshchevsky, G.A. (2018). Politicheskiye factory institucyonalnoy transformacyi gosudarstvennoi sluzhby [Political factors of institutional transformation of the state service]. Vestnik Moskovskogo universiteta, Seriya 18. Sociologiya i politologiya, 24(1) - Bulletin of the Moscow University, Series 1, Sociology and political science, 24(1), 210-231. DOI: 10.24290/1029-3736-2018-24-1-210-232 [in Russian].

Dosymbekova, R.Sh. (2015). Personnel Management in the Public Service in the Context of the Modernization Process in Kazakhstan. Management № 1(7), 102, 55-68. DOI: 10.12737/8789

Gov.kz. (2018). Agenstvo Respubliki Kazakhstan po delam gosudarstvennoi sluzhby [Agency for Public Service and Anti-Corruption]. Monitoring sostoyaniya kadrov gosudarstvennoi slyzhbi po sostoyaniyu na 1 yanvarya 2018 Monitoring the state of public service personnel as for 1 January 2018. https://www.gov.kz/memleket/entities/qyzmet/documents/details/4668?lang=ru [in Russian].

Kadyrov, A., \& Mynzhasarov, R.I. (2016). Sistema gosudarstvennogo upravleniya i gosudarstvennoi sluzhby v Respublike Kazakhstan [System of public administration and public service in the Republic of Kazakhstan]. Problemi ekonomiki i menedjmenta - Problems of Economics and Management, 1 (53), 146-151 [in Russian].

Mamitova, N.V. (2017). Osobennosti pravovogo regulirovaniya instituta gosudarstvennoi sluzhby v zarubezhnyh stranah [Features of legal regulation of the Institute of public service in foreign countries]. Obshchestvo $i$ pravo Society and Law, 1(59),158-162 [in Russian].

Nacyonalnyi doklad o sostoyanii gosudarstvennoi sluzhby po sostoyaniyu na 2017-2018 [National report on the state of public service in the Republic of Kazakhstan-Kazakhstan]. - 2020. - http://zkcontrol.kz/images/01/doc/2019ru.pdf [in Russian].

OECD-ilibrary.org. (2018). Benchmarking Civil Service Reform in Kazakhstan. https://www.oecdilibrary.org/governance/benchmarking-civil-service-reform-in-kazakhstan_9789264288096-en

Sheluntsova, A.M. (2018). Sistema upravleniya personalom v gosudarstvennom uchrezhdenii [The System of personnel management in a public institution]. Molodoi ucheniy - Young scientists, 3(189, 86-89. Retrieved from https://moluch.ru/archive/189/47954/ [in Russian].

Stat.gov.kz. (2019). Electronnyi resurs «Dannye Komiteta po statistike Respubliki Kazakhstan za 2011-2019» [Electronic resource: Data Of the Committee on statistics of the Republic of Kazakhstan for 2011-2019]. https://stat.gov.kz/ [in Russian].

Stelina J. (2019). Theoretical concepts of the law of civil servants. Law Enforcement Review, Vol. 3, no. 2, 21-30. DOI: 10.24147/2542-1514.2019.3(2).2130.

Suleimenova, G. (2016). Civil Service Training in Kazakhstan: The Implementation of New Approaches. Universal Journal of Educational Research, 4/10, 2359-2366. DOI: 10.13189/ujer.2016.041014

Zakon.kz. (2019). Ukaz Presidenta Respubliki Kazakhstan ot 22 iyulya 2019 goda №74 [Decree №4 of the President of the Republic of Kazakhstan dated July 22, 2019]. Polozheniye ob Agentstve Respubliki Kazakhstan po delam gosudarstvennoi sluzhby, №74 - Regulations on the Agency of the Republic of Kazakhstan for civil service Affairs, №74. https://online.zakon.kz/document/?doc_id=35160652 [in Russian]. 
Zakon.kz. (2020). Zakon Respubliki Kazahstan «O gosudarstvennoi sluzhbe Respubliki Kazakhstan» (s izmeneniyami i dopolneniyami po sostoyaniyu na 06.10 .2020 h.) [Law of the Republic of Kazakhstan «On public service of the Republic of Kazakhstan» (with amendments and additions as of 06.10.2020) https://online.zakon.kz/m/document/?doc_id=36786682 [in Russian].

Zhumagulov, M.I. (2019). Reformirovaniye sistemy strukturirovaniya institutov otrasli «Administrativnoye pravo Respubliki Kazakhstan» v sootvetstvii s deistvuyushim nacyonalnym zakonodatelstvom v oblasti gosudarstvennogo upravleniya [Reforming the system of structuring institutions of the "Administrative law of the Republic of Kazakhstan" branch in accordance with the current national legislation in the field of public administration]. Vestnik Instituta zakonodatelstva Respubliki Kazakhstan - Bulletin Of the Institute of legislation of the Republic of Kazakhstan, 1(55), 42-48 [in Russian].

Zqai.kz. (2019). Sbornik analiticheskih spravok po rezultatam pravovogo monitoringa (1 kvartal 2019 goda) [Collection of analytical reports on the results of legal monitoring (1st quarter of 2019)]. Institut zakonodatelstva Respubliki Kazakhstan - Institute of legislation of the Republic of Kazakhstan. http://www.zqai.kz/ru/journals/analitic-monitoring [in Russian].

\title{
Ю. Ким, А. Омарова
}

\section{Қазақстан Республикасының мемлекеттік басқару жүйесіндегі персоналды басқару ерекшеліктері}

\begin{abstract}
Аңдатпа:
Maқ̧cambl: Қазақстан Республикасында мемлекеттік қызметтің қалыптасуы мен қызмет ету саласында дамып келе жатқан әлеуметтік қатынастар, ұлттық тәжірибе мен шет елдердің тәжірибесі мемлекеттік қызмет жүйесіндегі персоналды басқарудың ғылыми негізделген және тәжірибеде тексерілген тұжырымдамалары мен ерекшеліктерін дамытпай және қолданбай тиімді мемлекеттік қызмет жүйесін құрудың мүмкін еместігін көрсетеді, бұл мемлекеттік қызметті құқықтық реттеудегі жүйелік қайшылықтарды жояды. Осыған байланысты, Қазақстан Республикасындағы мемлекеттік қызметтің теориясы мен практикасы мәселелеріне ғылыми қызығушылықтың өсуінің объективті негіздері бар.

Әдіci: Деректерді өңдеу және жүйелеу кезінде топтау және жіктеу әдістері, сондай-ақ математикалық модельдеу әдістері қолданылды. Эконометриялық модель жасалды.

Kорытынды: Қазақстан Республикасының мемлекеттік қызметі жүйесіндегі персоналды басқару ерекшеліктерін зерттей келе, мемлекеттік қызмет белгілі бір қағидаттарға негізделетіндігі анықталды, олар тұтастай алғанда мемлекеттік қызмет институтының функционалдығын қамтамасыз ететін талаптар және олардың негізінде Қазақстан Республикасы Статистика комитетінің деректері бойынша талданған жіктеу белгілері көрсетілген. Жұмыс күшін жоспарлау болашақты болжау және өзгертілетін мемлекеттік қызмет қажеттіліктеріне үнемді тәсілдермен жауап беру үшін қабылдануы мүмкін. Авторлар «мемлекеттік басқару және қорғаныс саласындағы қызметтер; міндетті әлеуметтік қамсыздандыру жөніндегі қызметтер» көрсеткіші мен «мемлекеттік басқару және қорғаныс; міндетті әлеуметтік қамсыздандыру саласы қызметкерлерінің тізімдік саны» және «мемлекеттік қызметшілердің орташа айлық жалақысы» сияқты факторлар арасында өзара байланыстың болуы туралы гипотеза ұсынды. Бұл гипотезаны дәлелдеу немесе жоққа шығару үшін регрессиялық талдау жүргізілді.

Тұжырымдама: Жүргізілген талдау негізінде нәтижелі көрсеткіштің регрессия теңдеуінде оң мәнге ие бола отырып, «мемлекеттік басқару және қорғаныс саласындағы қызметтер; міндетті әлеуметтік қамсыздандыру жөніндегі қызметтер» көрсеткіші мен «мемлекеттік басқару және қорғаныс саласы қызметкерлерінің тізімдік саны; міндетті әлеуметтік қамсыздандыру» және «мемлекеттік қызметшілердің орташа айлық жалақысы» факторлары арасында байланыстың болуы туралы гипотеза расталады деп сеніммен айтуға болады. Авторлар мемлекеттік қызметшілердің штаттарын жинақтау басқарудың қажетті процесі деген тұжырымға келген, өйткені мемлекеттік органдар қызметінің тиімділігі көбінесе тиімді мемлекеттік басқару үшін ресурстардың саны мен сапасына байланысты анықталады.
\end{abstract}

Kiлm сөздер: мемлекеттік қызмет, мемлекеттік саясат, даму стратегиясы, кадрлармен қамтамасыз ету, коммуникация, инновация, заманауи технологиялар, басқару.

\section{Ю. Ким, А. Омарова}

\section{Особенности управления персоналом в системе государственной службы Республики Казахстан}

\section{Аннотация}

Цель: Общественные отношения, складывающиеся в сфере формирования и функционирования государственной службы в Республике Казахстан, национальный опыт и опыт зарубежных стран указывают на невозможность создания эффективной системы государственной службы без разработки и применения научно обоснованных и выверенных на практике концепций и особенностей управления персоналом в системе государственной службы, которые бы позволили устранить системные противоречия в правовой регламентации государ- 
ственной службы. В этой связи рост научного интереса к проблемам теории и практики государственной службы в Республике Казахстан имеет объективные основания.

Memoдbl: При обработке и систематизации данных применялись методы группировок и классификации, а также математического моделирования. Была построена эконометрическая модель.

Результаты: Исследуя особенности управления персоналом в системе государственной службы Республики Казахстан, было выявлено, что государственная служба основывается на определённых принципах, которые выражаются в виде требований и классификационных признаков, на основе которых можно осуществлять кадровое планирование, способствующее прогнозированию ситуации в будущем и реагированию на изменение потребностей государственной службы экономически эффективными способами. Авторами была выдвинута гипотеза о наличии взаимосвязи между показателем «Услуги в области государственного управления и обороны; услуги по обязательному социальному обеспечению» и такими факторами, как «Списочная численность работников сферы «Государственное управление и оборона; обязательное социальное обеспечение» и «Среднемесячная заработная плата государственных служащих». Для доказательства или опровержения этой гипотезы был проведен регрессионный анализ.

Bblвoдbl: На основе проведенного анализа, получив положительное значение в уравнении регрессии результативного показателя, можно с уверенностью сказать, что выдвинутая гипотеза о наличии связи между показателем «Услуги в области государственного управления и обороны; услуги по обязательному социальному обеспечению» и выявленными факторами подтверждается.

Авторы приходят к выводу о том, что укомплектование штатов государственных служащих является необходимым процессом управления, так как результативность деятельности органов государственной власти во многом определяется тем, каково количество и качество ресурсов для осуществления эффективного государственного управления.

Ключевые слова: государственная служба, государственная политика, управление, стратегия развития, укомплектованные штаты, коммуникация, инновации, современные технологии.

\section{References}

Anufrieva A.A. Global Competitiveness Ensuring as a Main Priority of Cooperation in the Eurasian Economic Union area [Текст] / A.A. Anufrieva, N.S. Devyatova, E.R. Meteleva // Сб. избр. ст. по материалам науч. конф. Обществ. исслед. ин-та «Нацразвитие». - 2019. - № 1. - C. 87-92.

Bakhtairova E.A. Formation of a New Paradigm of Public Service in the Post-Soviet Eurasian Economic Union Countries (Belarus, Armenia, Kazakhstan and Kyrgyzstan) [Текст] / E.A. Bakhtairova // Изв. Байкал. гос. ун-та. 2019. - Vol. 29. — № 2. — C. 273-279. Doi: 10.17150/2500- 2759.2019.29(2).273-279.

Baranova S.A. (2018). Service Law as a New Branch of Russian Law: Problems of Formation and Development [Текст] / S.A. Baranova // Вопросы Российского и международного права. — 2018. — Vol. 8, № 3A. — C. 6470.

Bespalov, S.V. Reforming Civil Service in Kazakhstan [Текст] / S.V. Bespalov // Modern Research of Social Problems. — 2015. — № 11(55). C. 132-148. Doi: 10.12731 / 2218-7405-2015-11-12.

Dosymbekova, R.Sh. Personnel Management in the Public Service in the Context of the Modernization Process in Kazakhstan [Текст] / R.Sh. Dosymbekov // Управление. — 2015. — № 1(7), 102. — C. 55-68. Doi/10.12737/8789

Stelina J. Theoretical concepts of the law of civils servants [Текст] / J. Stelina // Law Enforcement Review. — 2019. — Vol. 3, № . 2. - C. 21-30. Doi:10.24147/2542-1514.2019.3(2).2130

Suleimenova, G. «Civil Service Training in Kazakhstan: The Implementation of NewApproaches» [Текст] / G.Suleimenova // Universal Journal of Educational Research. — 2016. — № 4/10. — C. 2359-2366. — (https://www.hrpub.org/journals/article_info.php? aid=5148)

Борщевский Г.А. Политические факторы институциональной трансформации государственной службы [Текст] / Г.А. Борщевский // Вестн. Моск. ун-та. Социология и политология. — 2018. — Сер. 18. — Т. 24. — № 1. — C. 210-231. Doi:10.24290/1029-3736-2018-24-1-210-232

Данные Комитета по статистике Республики Казахстан за 2011-2019 гг. - 2019. (https://stat.gov.kz/)

Жумагулов М.И. Реформирование системы структурирования институтов отрасли «Административное право Республики Казахстан» в соответствии с действующим национальным законодательством в области государственного управления [Текст] / М.И. Жумагулов // Вестн. Ин-та законодательства РК. — 2019. № $1(55)$. - С. $42-48$.

Кадыров А. Система государственного управления и государственной службы в Республике Казахстан [Текст] / А.Кадыров, Р.И. Мынжасаров // Проблемы экономики и менеджмента. — 2016. — № 1(53). — С. $146-151$.

Мамитова Н.В. Особенности правового регулирования института государственной службы в зарубежных странах [Текст] / Н.В. Мамитова // Общество и право. — 2017. — № 1(59). — С. 158-162.

Мониторинг состояния кадров государственной службы по состоянию 2017-2018 гг. - 2018. ( https://www.gov.kz/memleket/entities/qyzmet/documents/details/4668? lang=ru).

Национальный доклад о состоянии государственной службы в Республике Казахстан за 2019 г. - 2020. (http://zkcontrol.kz/images/01/doc/2019ru.pdf) 
О государственной службе Республики Казахстан (с изм. и доп. по состоянию на 06.10.2020 г.) [Текст]: Закон РК от 23 ноября 2015 г. № 416-V // Офиц. онлайн-публ. 2020. - 6 окт.

ОЭСР [Текст] / Benchmarking Civil Service Reform in Kazakhstan. — 2019. (https://www.oecdilibrary.org/governance/benchmarking-civil-service-reform-in-kazakhstan_9789264288096-en)

Сборник аналитических справок по результатам правового мониторинга (1 квартал 2019 г.) [Текст]: ГУ «Институт законодательства Республики Казахстан». — 2019. — № 139. (http://www.zqai.kz/ru/journals/analiticmonitoring)

Указ Президента Республики Казахстан от 22 июля 2019 года [Текст]. [Принят Указом Президента Республики Казахстан от 22 июля 2019 г. № 76] / 2019. — № 76. Положение об Агентстве Республики Казахстан по делам государственной службы. (https://online.zakon.kz/document/? doc_id=35160652)

Шелунцова А.М. Система управления персоналом в государственном учреждении [Текст] / А.М. Шелунцова // Молодой ученый. — 2018. — № 3(189). — C. 86-89. — (https://moluch.ru/archive/189/47954/). 